\title{
The BCL-2 protein family, BH3-mimetics and cancer therapy
}

\author{
ARD Delbridge ${ }^{1,2}$ and A Strasser ${ }^{*, 1,2}$
}

Escape from apoptosis is a key attribute of tumour cells and facilitates chemo-resistance. The 'BCL-2-regulated' or 'intrinsic' apoptotic pathway integrates stress and survival signalling to govern whether a cancer cell will live or die. Indeed, many pro-apoptotic members of the BCL-2 family have demonstrated tumour-suppression activity in mouse models of cancer and are lost or repressed in certain human cancers. Conversely, overexpression of pro-survival BCL-2 family members promotes tumorigenesis in humans and in mouse models. Many of the drugs currently used in the clinic mediate their therapeutic effects (at least in part) through the activation of the BCL-2-regulated apoptotic pathway. However, initiators of this apoptotic pathway, such as p53, are mutated, lost or silenced in many human cancers rendering them refractory to treatment. To counter such resistance mechanisms, a novel class of therapeutics, 'BH3-mimetics', has been developed. These drugs directly activate apoptosis by binding and inhibiting select antiapoptotic BCL-2 family members and thereby bypass the requirement for upstream initiators, such as $p 53$. In this review, we discuss the role of the BCL-2 protein family in the development and treatment of cancer, with an emphasis on mechanistic studies using well-established mouse models of cancer, before describing the development and already recognised potential of the BH3-mimetic compounds. Cell Death and Differentiation (2015) 22, 1071-1080; doi:10.1038/cdd.2015.50; published online 8 May 2015

\section{Facts}

- Cancer development and progression are facilitated by enhanced cell survival signalling.

- Loss of initiators of apoptosis or overexpression of inhibitors of apoptosis are frequently observed in haematological and solid cancers.

- BH3-mimetic compounds offer a novel approach for treating chemo-resistant cancers by blocking select pro-survival BCL-2 family members.

\section{Open Questions}

- Do all cancers require high expression of pro-survival BCL-2 family members for their development and sustained growth?

- Can a therapeutic window be established for BH3mimetic drugs?
- Will direct induction of apoptosis using BH3-mimetic compounds reduce the emergence of therapeutic resistance?

- What are the optimal drugs to partner BH3-mimetics for combination therapy of different cancers?

The complexity of multicellular animals is built upon a foundation of cell and tissue specification that facilitates coordination of intra-organismal processes and interaction with the surrounding environment. Cooperation between cells is essential, as are mechanisms to detect and remove 'rogue' cells that lose the ability to respond appropriately to developmental and homeostatic cues. Failure of these mechanisms can have dire consequences, such as the development of cancer or autoimmune disease. ${ }^{1}$ A critical tumoursuppression mechanism is the cell's intrinsic ability to selfdestruct through a process of programmed cell death known as apoptosis. ${ }^{2}$ Indeed, evasion from apoptosis cooperates with oncogenic mutations that deregulate cell growth and cell

\footnotetext{
${ }^{1}$ The Walter and Eliza Hall Institute of Medical Research, Parkville, Victoria, Australia and ${ }^{2}$ Department of Medical Biology, University of Melbourne, Melbourne, Victoria, Australia

*Corresponding author: A Strasser, The Walter and Eliza Hall Institute of Medical Research, 1G Royal Parade, Parkville, Victoria 3050, Australia. Tel: +69 39345 2555; Fax: +61 39347 0852; E-mail: strasser@wehi.edu.au

Abbreviations: BCL-2, B cell lymphoma gene 2; BH, BCL-2 homology region; BAX, BCL-2-associated protein X; BAK, BCL-2-antagonist/killer; MCL-1, myeloid cell leukaemia gene 1; A1, BCL-2-related protein A1; BIM, BCL-2 interacting mediator of cell death; PUMA, p53 upregulated modulator of apoptosis; BID, BH3 interactingdomain death agonist; BAD, BCL-2-associated death promoter; BIK, BCL-2-interacting killer; HRK, Harakiri; BMF, BCL-2-modifying factor; tBID, truncated BID; MOMP, mitochondrial outer membrane permeabilisation; FOXO, forkhead box protein O; ER, endoplasmic reticulum; CHOP, C/EBP homologous protein; AKT, v-akt murine thymoma viral oncogene homolog; ASCIZ, ATM/ATR-substrate CHK2-interacting zinc finger protein; DLC1, dynein light chain 1; miRNA, microRNA; MYC, v-myc avian myelocytomatosis viral oncogene homolog; IgH, immunoglobulin heavy chain; IgL, immunoglobulin light chain; AML, acute myeloid leukaemia; CLL, chronic lymphocytic leukaemia; BOK, BCL-2 related ovarian killer; BL, Burkitt lymphoma; RNAi, RNA interference; HDACi, histone deacetylase inhibitors; MEK, MAPK/ERK kinase; EGFR, epidermal growth factor receptor; CML, chronic myeloid leukaemia; VEGFR, vascular endothelial growth factor receptor; BCR-ABL, break point cluster region - Abelson kinase fusion protein

Received 08.2.15; revised 20.3.15; accepted 24.3.15; Edited by G Melino; published online 08.5.15
} 
cycling in tumorigenesis. Evasion of apoptosis is therefore considered a requisite characteristic of tumour formation, one of the so-called 'Hallmarks of Cancer'. ${ }^{3}$

Apoptosis constitutes the ordered, genetically encoded process that removes not only damaged cells but also those that have become superfluous to the function of the organism. ${ }^{4}$ Apoptosis enables cells to be eliminated with minimal disruption to surrounding cells and is thereby distinct from necrotic cell death, which is often unregulated and results in the release of cellular debris that can prompt tissue inflammation. It is important to note that some other forms of programmed cell death, known as pyroptosis, ${ }^{5}$ and necroptosis (also called programmed necrosis), ${ }^{4,6}$ have risen to prominence. However, the contributions of these forms of cell death to morphogenesis during animal development, adult tissue homeostasis as well as the genesis and treatment of cancer remain to be elucidated.

The term 'apoptosis' was first coined by Kerr et al. ${ }^{7}$ to describe a form of cell death distinguished from necrosis by a characteristic morphology. Apoptosis is associated with cell shrinkage and membrane blebbing to yield small vesicles, which are subsequently engulfed by neighbouring phagocytic cells. ${ }^{8-10}$ In addition, molecular events, such as inter-nucleosomal DNA cleavage and translocation of phosphatidyl-serine to the outer leaflet of the plasma membrane, are indicative of apoptosis and frequently used experimentally as markers of apoptosis.

In this review, we summarise the literature describing the mechanisms by which apoptosis signalling is governed with particular focus on their importance in cancer development as demonstrated by observations from various experimental mouse models and also from studies of human cancer. We close with an analysis of the role of the BCL-2 family for mediating the activity of many commonly used anticancer therapeutics, including the promising new class of agents known as $\mathrm{BH} 3-$ mimetics.

\section{The BCL-2-Regulated Apoptotic Pathway}

The BCL-2-regulated apoptotic pathway (also known as 'intrinsic', 'stress' or 'mitochondrial' pathway) is evolutionarily highly conserved, with homologues of critical genes found in animals as distantly related as worms and humans. ${ }^{11-13}$ Indeed, many of the early insights into the roles of components of this cell death pathway were derived from studies using the model organism Caenorhabditis elegans (e.g., Vaux et al.). ${ }^{12}$ Initiation of the BCL-2-regulated apoptotic pathway is controlled, as the name implies, by interactions between members of the BCL-2 protein family. ${ }^{14-19}$ This family consists of three groups of structurally related proteins: the pro-survival BCL-2like proteins, the multi-BH domain pro-apoptotic BAX/BAK proteins, and the pro-apoptotic $\mathrm{BH} 3$-only proteins.

The BCL-2 protein family. The pro-survival BCL-2 family proteins (BCL-2, BCL-XL, BCL-W, MCL-1, A1/BFL-1) share homology within four BCL-2 homology domains (BH1-4). These proteins form a characteristic helical bundle fold, which is critical for their ability to bind to the pro-apoptotic BCL-2 family members and thereby exert their antiapoptotic function.
The pro-apoptotic BAX/BAK subfamily members also contain four $\mathrm{BH}$ domains (BH1-4). In their inactive state, their structure is very similar to that of $B C L-2$ pro-survival proteins, ${ }^{20}$ but $\mathrm{BAX}$ and $\mathrm{BAK}$ are able to undergo substantial conformational change during apoptosis. ${ }^{21} \mathrm{BAX}$ and $\mathrm{BAK}$ bind to and are inhibited by different BCL-2-like pro-survival proteins to different extents. ${ }^{22,23}$ BOK shares significant homology across all four $\mathrm{BH}$ domains to BAX and BAK; however, its role in apoptosis remains unclear, ${ }^{24}$ although it may cooperate with $\mathrm{BAX}$ in the attrition of primordial follicle oocytes during ageing. ${ }^{25}$

The pro-apoptotic BH3-only proteins (BIM, PUMA, BID, $B A D, B I K, B M F, N O X A, H R K$ ) share only the $B H 3$ domain with each other and their more distant relatives. ${ }^{19,26,27}$ These proteins are unstructured in isolation but assume an $a$-helical fold when bound to BCL-2 pro-survival family members. ${ }^{28}$ The exception to this rule is BID, which is produced as an inactive globular protein that is converted into its active form, tBID (truncated BID), through caspase-8-mediated cleavage. ${ }^{29,30}$ The BH3-only proteins are able to bind members of the BCL-2like pro-survival subfamily and some of them can also bind to BAX and BAK, but there are substantial differences in their selectivity of interaction. ${ }^{17-19,23,31-33}$

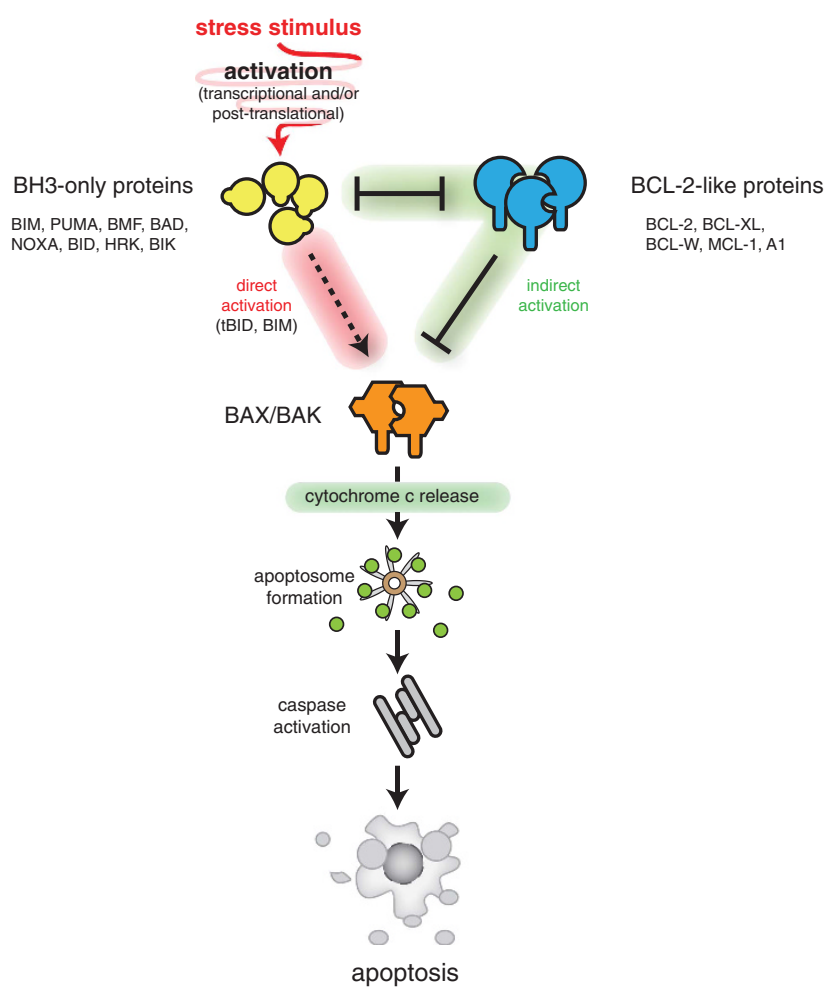

Figure 1 The BCL-2 family members interact to regulate initiation of apoptosis. In healthy cells, the BCL-2-like pro-survival proteins safeguard mitochondrial outer membrane integrity and cell survival by preventing the activation of BAX and BAK. Under conditions of stress, the BH3-only proteins are activated transcriptionally and/or posttranscriptionally to induce apoptosis by releasing BAX/BAK from inhibition by the BCL-2-like proteins or in the case of certain BH3-only proteins (notably $\mathrm{BIM}, \mathrm{tBID}, \mathrm{PUMA}$ ) by activating BAX/BAK through direct binding. Once activated, BAX/BAK cause mitochondrial outer membrane permeabilisation (MOMP) with consequent release of apoptogenic molecules (e.g., cytochrome $c$, SMAC/DIABLO) that cause activation of the caspase cascade that culminates in cellular demolition 
Activation of the BCL-2-regulated apoptotic pathway. The BCL-2 regulated apoptotic pathway is initiated through the transcriptional and/or posttranscriptional activation of the $\mathrm{BH} 3-$ only proteins in response to various upstream signalling events. Some BH3-only proteins (notably BIM, tBID, PUMA) cause activation of $\mathrm{BAX} / \mathrm{BAK}$ through direct binding, and all $\mathrm{BH} 3-$ only proteins can activate BAX/BAK indirectly by binding to and inhibiting the pro-survival $B C L-2$-like proteins (Figure 1). ${ }^{19,34-39}$ Activated BAX/BAK cause outer mitochondrial membrane permeabilisation (MOMP), which allows cytosolic release of apoptogenic factors (e.g., cytochrome $c$, Smac/DIABLO) that cause activation of the caspase cascade. ${ }^{40}$ It remains unclear whether binding of BH3-only proteins to the pro-survival BCL-2-like proteins or their direct binding to $B A X / B A K$ is more critical for the initiation of apoptosis. ${ }^{37,38,41}$ It is, however, clear that some of the $\mathrm{BH} 3-$ only proteins are more potent inducers of apoptosis (e.g., BIM, PUMA, tBID) than others (e.g., BAD, NOXA, BMF). Pertinently, the potent $\mathrm{BH} 3-$ only proteins bind avidly to all prosurvival BCL-2 family members and can also engage BAX/ $\mathrm{BAK}$, whereas the less potent ones have more select binding specificities for the pro-survival BCL-2 family members and reportedly do not bind to $\mathrm{BAX}$ or BAK. ${ }^{31,32}$

Mechanisms of BH3-only protein activation. Because of their position at the apex of the BCL-2-regulated apoptotic pathway, the $\mathrm{BH} 3-o n l y$ proteins act as a fulcrum, determining whether the scales tip in favour of cell death or in favour of cell survival.

The mechanisms that lead to activation of the BH3-only proteins vary between members of this subfamily and also according to the apoptotic stimulus. ${ }^{26,27,42}$ Transcriptional activation features prominently; however, emerging evidence also identifies posttranscriptional mechanisms, such as those involving microRNAs (miRNAs), as important in certain contexts.

For example, following DNA damage the tumoursuppressor p53 is posttranslationally activated and then transcriptionally upregulates PUMA and NOXA. ${ }^{43-45}$ E2F1 is also able to induce PUMA and NOXA. ${ }^{46}$ PUMA as well as BIM expression were reported to be induced by the transcription factor FOXO3a in response to cytokine withdrawal. ${ }^{47-49}$ However, mutation of all known FOXO transcription factorbinding sites in the Bim gene had no impact on haematopoietic cell homeostasis and apoptosis, ${ }^{50}$ indicating that this mode of induction may not be critical for BIM activation. In response to ER stress, BIM expression can be transcriptionally induced by $\mathrm{CHOP}^{51}$

Various posttranslational processes were reported to regulate the stability and thereby control the activity of $\mathrm{BH}$ only proteins. BIM and BAD were reported to be negatively regulated by phosphorylation. ${ }^{42,52}$ Phosphorylation of BAD by AKT was shown to cause its sequestration in the cytosol by 14-3-3 proteins, thereby restraining its pro-apoptotic activity. ${ }^{53}$ Mice lacking BAD are largely normal, and their cells do not show marked resistance to the apoptotic stimuli tested. ${ }^{54,55}$ The role of BAD in programmed and stress-induced cell death is therefore probably relatively subtle and ancillary to the action of more potent BH3-only proteins (e.g., BIM, PUMA). Phosphorylation of BIM by ERK was reported to be critical for the antiapoptotic activity of this kinase.$^{56-60}$ However, a recent study has shown that ERK-mediated direct phosphorylation of BIM does not have a major role in the control of the proapoptotic activity of this $\mathrm{BH}$-only protein within the whole animal. ${ }^{61}$ Both BIM and BMF were shown to be sequestered by binding to elements of the cytoskeleton, thereby restraining their pro-apoptotic activity. ${ }^{62,63}$ Interestingly, loss of the transcription factor $\mathrm{ASClZ}$, with consequent reduction in its target dynein light chain 1, which reportedly links BIM to the dynein motor complex, ${ }^{62}$ causes abnormal death of $B$ lymphoid cells, and this can be blocked by concomitant loss of BIM. $^{64}$ This suggests that this mode of BIM regulation has a critical role in normal physiology.

The expression of the $\mathrm{BH} 3$-only proteins can be modulated posttranscriptionally through the activity of miRNA. These short (17-25 nucleotides) RNA species bind in a sequencespecific manner to several target mRNA transcripts and inhibit their translation either through translation inhibition or mRNA destabilisation. Although the change in mRNA transcript abundance for any single miRNA target is mostly relatively minor, individual miRNAs are able to exert marked effects by targeting multiple mRNA species-encoding proteins that act within the same signalling pathway.

With respect to the $\mathrm{BH} 3-$ only proteins, several miRNA have been implicated in the regulation of BIM expression, including the miR-17 92 cluster in mice ${ }^{65,66}$ and in human cancer cell lines also (miR-32, miR-17-5p, miR-106-25). ${ }^{67-69}$ PUMA was

Table 1 The role of the BCL-2 protein family members in tumour development

\begin{tabular}{|c|c|c|c|}
\hline Gene & Role in tumorigenesis & Model & References \\
\hline $\operatorname{Bim}(B c / 2 / 11, B o d)$ & Tumour suppressor & $E \mu-M y c$ & 89,90 \\
\hline Puma (Bbc3) & Tumour suppressor & $E \mu-M y c$ & 91 \\
\hline Puma (Bbc3) & Required for tumour initiation & Irradiation-induced lymphoma & 111,112 \\
\hline Bax & Tumour suppressor & 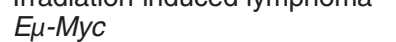 & 92 \\
\hline$B m f$ & Tumour suppressor & Irradiation-induced lymphoma & 110 \\
\hline Noxa (Pmaip1) & Tumour suppressor & Irradiation-induced lymphoma & 111 \\
\hline $\mathrm{Bad}(\mathrm{Bbc2})$ & Conflicting reports & Irradiation-induced lymphoma & 54,55 \\
\hline $\mathrm{Bcl} 2$ & Oncogene & 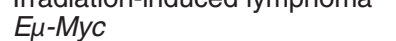 & 86 \\
\hline$B c / x(B c / 2 / 1)$ & Oncogene; required for lymphoma initiation & E $\mu-M y c$ & $87,90,93,94$ \\
\hline $\mathrm{Mcl1}$ & Oncogene; required for sustained lymphoma growth & $E \mu-M y c$ & 88,97 \\
\hline $\mathrm{Mcl1}$ & Oncogene; required for sustained lymphoma growth & p53-deficient thymic lymphoma & 108 \\
\hline $\mathrm{Mcl1}$ & Required for sustained lymphoma growth & $A M L$ & 113,114 \\
\hline
\end{tabular}


reported to be regulated by miR-483-3p, miR-221 and miR-222. ${ }^{70,71}$

As for the pro-survival BCL-2 family members, BCL-2 and MCL-1 appear to be the prominent targets of miRNA-mediated regulation. Both are targeted by miR-29 and miR-153, ${ }^{72-74}$ and $B C L-2$ expression is also regulated by miR-15, miR-16, ${ }^{75}$ miR-195 ${ }^{76}$ and the p53-inducible miR-34. ${ }^{77}$ BCL-XL expression appears to be controlled by miR-491. ${ }^{78}$

\section{Role of the BCL-2-Regulated Apoptotic Pathway in Mouse Models of Tumorigenesis}

Experimental models have been utilised to delineate the roles of the various BCL-2 family proteins during tumorigenesis (Table 1). Because of the prominent expression of the prosurvival BCL-2 family members in the haematopoietic system, ${ }^{79}$ a large proportion of these studies have focussed on the role these proteins have during leukaemia and lymphoma development.

E $\boldsymbol{\mu}-$ Myc lymphoma model. MYC expression is thought to be deregulated in $\sim 70 \%$ of human cancers. ${ }^{80}$ In Burkitt lymphoma $(\mathrm{BL})$, this is due to a chromosomal translocation that subjugates the $c-M y c$ gene to the control of the immunoglobulin heavy $(\mathrm{lgH})$ or light chain gene enhancers. The E $\mu-M y c$ transgenic mice were generated to model this malignancy with expression of the $c-M y c$ proto-oncogene driven by the $\mathrm{IgH}$ gene enhancer, $E \mu .{ }^{81}$ Early in life, these mice contain abnormally increased numbers of large, cycling B-cell progenitors, ${ }^{82}$ which comprise the nascent neoplastic cells. $^{83}$ Upon acquisition of oncogenic mutations that cooperate with MYC in neoplastic transformation, clonal malignant pre-B or $\mathrm{slg}^{+} \mathrm{B}$ lymphomas emerge from the pool of preleukaemic B lymphoid cells. ${ }^{83}$ On a C57BL/6 background, median (50\%) survival is $\sim 110$ days, and all animals succumb to lymphoma within $\sim 350-400$ days. Tumour cells from lymphoma-bearing mice can be readily transplanted into syngeneic (immune-competent) recipients or adapted to grow indefinitely in vitro as cell lines. ${ }^{81,83}$ These two features and the ability to identify and study a preneoplastic cell population (see above) made this the most widely used animal model of human cancer ( $>1400$ publications).

Deregulated MYC expression promotes neoplastic transformation by causing aberrant cell proliferation. However, under conditions of stress, such as limited supply of growth factors or nutrients, deregulated MYC expression also increases the predisposition of cells to undergo apoptosis. ${ }^{84,85}$ Preleukaemic B lymphoid cells from E $\mu-M y c$ mice are highly prone to undergo apoptosis, ${ }^{85}$ and apoptosis constitutes a major mechanism to suppress/delay lymphoma development in $E \mu-M y c$ mice. Accordingly, overexpression of pro-survival BCL-2 family members (e.g., BCL-2, ${ }^{86} \mathrm{BCL}-\mathrm{XL}^{87}$ or $\mathrm{MCL}-1^{88}$ ) greatly accelerate lymphoma development in $E \mu$ Myc mice. Loss of BIM, ${ }^{89,90}$ PUMA $^{91}$ or BAX ${ }^{92}$ (but curiously not loss of BAK) also accelerate MYC-induced lymphomagenesis, indicating that these pro-apoptotic proteins are major tumour suppressors in this context.

Studies using gene-targeted mice or pharmacological inhibitors revealed that endogenously controlled expression of BCL-XL, ${ }^{90,93,94}$ but not BCL-2, ${ }^{95}$ is essential for MYC- induced lymphoma development. This may be explained by the fact that $B C L-X L$, but not $B C L-2$, is expressed at readily detectable levels in pro-B/pre-B cells, the population of preleukaemic cells from which malignant lymphoma is thought to arise in $E \mu-M y c$ mice. However, lymphomas initiated by combined overexpression of MYC and BCL-2 need high $\mathrm{BCL}-2$ expression for their continued survival. ${ }^{96}$

Interestingly, although $\mathrm{BCL}-\mathrm{XL}$ is critical for the development of pre-B/B lymphoma in $E \mu-M y c$ mice, it is dispensable for the sustained survival and expansion of these tumours. ${ }^{97}$ Instead, MCL-1 is essential, with loss of even a single allele of $M c l-1$ abrogating the in vivo growth of malignant $E \mu-M y c$ lymphomas, unless they have acquired a mutation in the tumour-suppressor gene $p 53 .^{97}$

p53-deficient mice, a model of Li-Fraumeni syndrome. Mutation or loss of $p 53$ is the most frequent mutation in human cancer and is frequently associated with poor prognosis and chemoresistance. ${ }^{98,99}$ Furthermore, a rare genetic disorder, Li-Fraumeni syndrome results from the inheritance of a single mutated copy of the p53 gene. ${ }^{100,101}$ These patients are characterised by a high incidence of early onset of various cancers, particularly lymphoma, leukaemia and several forms of sarcoma, which develop following the somatic loss of the remaining wild-type p53 allele in cancerinitiating cells.

The $p 53^{+/-}$heterozygous mice recapitulate the human condition ${ }^{102,103}$ and mice completely deficient for p53 rapidly (within 150-280 days) develop thymic lymphoma with 100\% penetrance on the C57BL/6 genetic background. These mice have been widely used to examine the importance of p53mediated tumour suppression and the consequences of its loss during lymphomagenesis. As p53 induces apoptosis through the BH3-only proteins PUMA and (to a lesser extent) NOXA, ${ }^{43-45}$ it was a great surprise that mice double deficient for both PUMA and NOXA displayed no propensity to tumour formation. ${ }^{104}$ Even the combined loss of p53's ability to induce apoptosis, cell cycle arrest and senescence (Puma ${ }^{-1-} \mathrm{Noxa}^{-1-} \mathrm{p} 21^{-1-}$ mice) did not render mice tumour prone. ${ }^{105-107}$ The precise mechanisms by which p53 suppresses tumour development therefore remain unclear.

A recent study has delineated the roles of the different prosurvival BCL-2 family members required for lymphoma development and expansion in p53-deficient mice. ${ }^{108} \mathrm{MCL}-1$ was found to be critical for both the development and sustained growth of lymphoma initiated by p53 deficiency, whereas BCL-XL was dispensable. This study showed that even for p53-deficient tumours therapeutic targeting of MCL-1 may represent an effective treatment strategy.

Y-radiation-induced thymic lymphoma model. Thymic lymphoma can be induced in mice by repeated exposure to low doses of $\gamma$-radiation. ${ }^{109}$ This is thought to facilitate neoplastic transformation through the sequential accumulation of oncogenic mutations in immature haematopoietic progenitors in the bone marrow, ultimately culminating in malignant lymphoma. Following exposure to $1.5 \mathrm{~Gy} \gamma$-irradiation weekly for 4 weeks, mice typically succumb to thymic lymphoma around 150-200 days. In this experimental model, NOXA and BMF have been shown to suppress lymphoma 
development, ${ }^{110,111}$ while the role of BAD remains contentious with one report describing accelerated thymic lymphomagenesis in BAD-deficient mice while another publication reported no effect. ${ }^{54,55}$ Possible explanations for the discrepancy might include differences in $y$-radiation dosing and schedule used or differences in genetic background (C57BL/6 ${ }^{55}$ versus complicated mixed background ${ }^{54}$ ). Loss of BIM alone did not accelerate lymphoma development; however, mice deficient for both BAD and BIM showed accelerated tumour development. ${ }^{55}$

Remarkably, loss of PUMA completely abrogated $\gamma$-radiation-induced thymic lymphoma development. ${ }^{111,112}$ This striking finding could be attributed to the profound resistance of PUMA-deficient white blood cells to DNA damage-induced apoptosis. The persistence of these cells obviated the need for mobilisation and burst of proliferation of haematopoietic stem/ progenitor cells that would normally occur to repopulate the depleted haematopoietic system, ${ }^{111,112}$ a process that appears to be required for lymphoma development in this model. ${ }^{109}$ These observations suggest that accumulation of DNA lesions, some of them potentially oncogenic, is not sufficient to induce tumour formation unless it is also accompanied by a drive for proliferative expansion of the mutation bearing leukaemia/lymphoma-initiating cells.

Acute myeloid leukaemia (AML) models. AML can be induced experimentally in mice by transducing haematopoietic stem/progenitor cells with expression constructs encoding protein products encoded by recurrent chromosomal translocations found in human AML (e.g., MLL-ENL, AML-ETO9a). Using this system, MCL-1, but not BCL-XL, BCL-2 or BCL-W, was shown to be critical for the sustained survival of $A M L$ cells in vitro and in vivo. ${ }^{113,114}$

Collectively, these results characterise the process of tumour formation as a sustained effort of nascent neoplastic cells to cope with stress conditions imposed by the oncogenic lesions, genomic instability and potentially cytotoxic signals from their environment. Mutations that sensitise cells to apoptosis, such as loss of pro-survival BCL-2 family members, act to suppress tumour development, whereas loss of pro-apoptotic BCL-2 family members expedite neoplastic transformation.

\section{Role of the BCL-2-Regulated Apoptotic Pathway in Human Cancer}

The BCL-2 family of proteins have also been shown to be critical for the development, progression and treatment responses of human cancers (Table 2). Indeed, the BCL-2 gene itself was discovered following its identification as the oncogene activated by the $t(14 ; 18)$ chromosomal translocation in follicular lymphoma. ${ }^{115}$ The seminal discovery by Vaux et al. ${ }^{116}$ that enforced BCL-2 expression could protect cells from growth factor deprivation-induced death revealed for the first time that defects in apoptosis could cause cancer.

Studies using human cancer-derived cell lines and patient samples revealed abnormalities in the expression of several anti- as well as pro-apoptotic BCL-2 family members in a broad range of malignancies. In addition to the critical role of BCL-2 in follicular lymphoma, high levels of BCL-2 expression have also been observed in neuroblastoma and chronic lymphocytic leukaemia (CLL). ${ }^{117-120}$ In at least some cases of CLL, this is likely due to loss of miR-15a and miR-16-1, which can repress BCL-2 expression. ${ }^{75}$ Amplifications of the $\mathrm{Mcl}-1$ or $\mathrm{BCl}-x$ gene loci have been identified as frequently occurring somatically acquired copy number aberrations in lung, breast $^{121,122}$ and giant-cell tumours of the bone. ${ }^{123}$ RNAi-mediated knockdown of $\mathrm{MCL}-1$ or $\mathrm{BCL}-\mathrm{XL}$ induced killing of some cell lines derived from such cancers, suggesting that these pro-survival BCL-2like proteins are essential for their sustained survival. ${ }^{121}$ Furthermore, MCL-1 levels were found to be high in primary AML samples and antagonising MCL-1 activity (using inducible expression of BIM variants that only bind to and inhibit MCL-1) impaired the in vitro survival of primary human AML cells. ${ }^{113,114}$ BFL-1, the human homologue of $A 1$, was shown to be overexpressed and associated with chemo-resistance in various cancers, including B-CLL. ${ }^{124-126}$

Pro-apoptotic BCL-2 family members were also found to be deregulated in human cancers. The genomic regions harbouring PUMA and BOK commonly show somatically acquired loss of copy number in various cancer types. ${ }^{121}$ Loss of BAX function appears likely to have a role in colon cancer development, with frame-shift mutations in the $B A X$ gene detected in $\sim 50 \%$ of colon cancers of the microsatellite mutator phenotype. ${ }^{127}$ Combined loss of BAX and BAK was observed in a small number of AML samples from heavily pretreated patients; treatment may have selected for tumour

Table 2 Aberrations in BCL-2 protein family members in human cancer

\begin{tabular}{lll}
\hline Gene & Expression & Cancer \\
\hline BIM (BCL2I11, BOD) & Genomic loss & Mantle cell lymphoma \\
$B I M(B C L 2 / 11, B O D)$ & Epigenetic silencing & Burkitt lymphoma \\
$P U M A(B B C 3)$ & Genomic loss & Various \\
$P U M A(B B C 3)$ & Epigenetic silencing & Burkitt lymphoma \\
$B M F$ & Genomic loss & Advanced lung, breast cancer \\
$B O K$ & Genomic loss & Various \\
$B A X$ & Genomic loss & Colon cancer \\
$B C L 2$ & Overexpressed & Follicular lymphoma, neuroblastoma, CLL \\
$B C L 2 L 1(B C L X)$ & Amplified & Lung cancer \\
$M C L 1(B C L 2 L 3)$ & Amplified & Lung cancer, breast cancer \\
$M C L 1(B C L 2 L 3)$ & Overexpressed & AML \\
$B F L-1(B C L 2 A 1)$ & Overexpressed & B-CLL; various solid cancer \\
\hline
\end{tabular}


cells with loss of both of these multi-BH domain pro-apoptotic BCL-2 family members. ${ }^{113}$ Homozygous loss of the Bim gene is seen in $\sim 15-20 \%$ of mantle cell lymphomas. ${ }^{128}$ Moreover, in $\mathrm{BL}$, the BIM and PUMA genes were found to be silenced by epigenetic alterations, such as hyper-methylation. ${ }^{129,130}$ Furthermore, the region harbouring the BMF gene is lost in late stage lung and breast cancer. ${ }^{131}$

These observations demonstrate that abnormalities in antias well as pro-apoptotic BCL-2 family members can contribute to the development of cancer in humans.

\section{The Role of the BCL-2-Regulated Apoptotic Pathway in Cancer Therapy}

Because of their role as mediators of apoptosis triggered by diverse cell stresses, the BCL-2 protein family members are key determinants of the response of tumour cells to a broad range of commonly used anticancer therapeutics (Figure 2). Accordingly, direct activation of the BCL-2-regulated apoptotic pathway using small-molecule mimetics of the pro-apoptotic

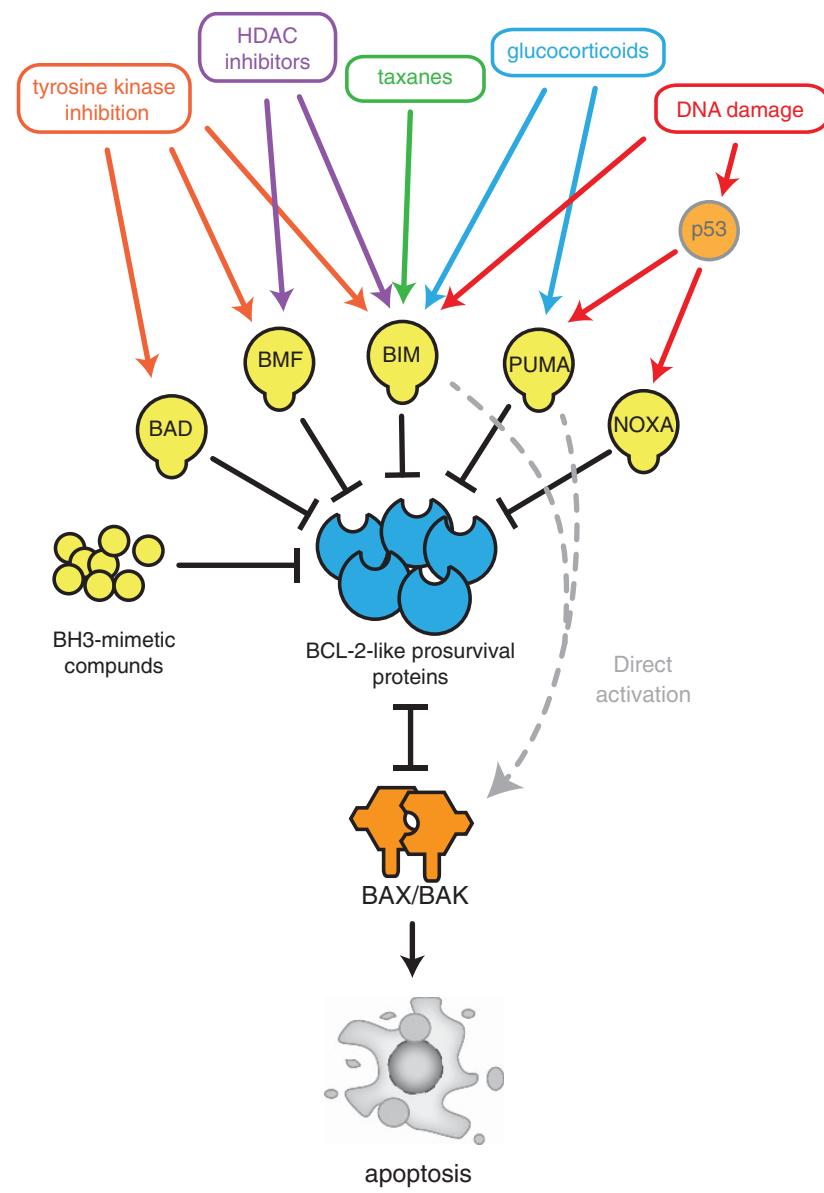

Figure 2 Many anticancer agents mediate tumour cell killing though activation of the BCL-2-regulated apoptotic pathway. BH3-only proteins are activated transcriptionally and/or posttranscriptionally in a cytotoxic stimulus-specific manner by many anticancer agents, often with 2-3 members cooperating to induce apoptosis. $\mathrm{BH}$ mimetic compounds bind directly to and block the BCL-2 pro-survival proteins and thereby elicit apoptosis even in cells lacking upstream activators of $\mathrm{BH}$-only proteins, such as the tumour-suppressor p53, which is critical for transcriptional induction of Puma and Noxa
BH3-only proteins is being developed as a novel strategy for cancer therapy.

The role of the BCL-2-regulated apoptotic pathway in the response to anticancer therapeutics was first demonstrated when it was found that non-transformed lymphoid cells from $\mathrm{BCl}-2$ transgenic mice ${ }^{132}$ and $\mathrm{BCL}-2$-overexpressing lymphoma cells ${ }^{133}$ were profoundly resistant to $\gamma$-irradiation, DNA damage-inducing chemotherapeutic drugs (e.g., etoposide) and glucocorticoids (e.g., dexamethasone). Similar protection from chemotherapeutic drug-induced apoptosis can be afforded by overexpression of any of the other prosurvival BCL-2 family members. ${ }^{134-137}$

Studies using gene-targeted mice or RNAi-mediated gene knockdown in cell lines revealed which pro-apoptotic BCL-2 family members are critical for cell killing by which anticancer agent. Consistent with the notion that BAX and BAK have essential overlapping functions in the BCL-2-regulated apoptotic pathway, cells from $\mathrm{Bax}^{-/} \mathrm{Bak}^{-/}$mice are markedly resistant to diverse anticancer agents. ${ }^{138-140}$ Notably, different anticancer agents require different $\mathrm{BH} 3$-only proteins for cell killing. PUMA is critical for therapeutic responses to $\gamma$-irradiation as well as to DNA-damaging drugs, with contributions from NOXA and also BIM (which does not appear to be a direct transcriptional target of p53) in at least certain non-transformed and malignant cell types. ${ }^{141-145}$ PUMA and BIM together account for most of the proapoptotic activity of glucocorticoids. ${ }^{141,143,146-149}$ BIM is also critical for taxane-induced cell killing. ${ }^{150,151}$ Furthermore, BMF as well as BIM are critical for the killing of non-transformed lymphoid cells as well as certain lymphoma cells by inhibitors of histone deacetylases. ${ }^{110,135}$ BIM (with BAD and BMF also contributing) is critical for the killing of tumour cells that are dependent on oncogenic kinases by therapeutic agents that block their activity, such as inhibitors of MEK (acting downstream of mutant B-RAF in melanoma or colon carcinoma), ${ }^{152}$ EGFR (lung cancer), ${ }^{153-155}$ BCR-ABL $(C M L)^{156,157}$ and VEGFR signalling (tumour angiogenesis). ${ }^{158}$ Notably, a gene polymorphism that impairs the expression of BIM was found to explain the de novo resistance of BCR-ABL-driven CML to Gleevec and mutant EGFR-driven lung cancer to Iressa/ Tarceva in East Asian populations. ${ }^{159}$

Anticancer drug-induced killing of tumour cells requires activation of $\mathrm{BH}$-only proteins by upstream signalling mediators, such as p53 or the glucocorticoid receptor. These upstream signal activators are frequently mutated, lost or silenced (e.g., due to epigenetic modifications) during tumour development or subsequently during emergence of therapyresistant cancer cells. ${ }^{14,27,160}$ To bypass such resistance mechanisms, a new class of therapeutics, known as 'BH3-mimetics', that directly activate apoptosis have been developed (Figure 2). BH3-mimetics bind and inhibit the pro-survival BCL-2 family members and thereby activate apoptosis in cancer cells. ${ }^{16}$ ABT-737 and its clinical analogue ABT-263 (navitoclax) exemplify this new therapeutic class, with the latter compound currently in phase 2 clinical trials. ${ }^{161,162}$ Both compounds bind to BCL-2, BCL-XL and BCL-W (but not to MCL-1 or A1) displacing the endogenous BH3-only proteins, which can then bind to MCL-1, A1 and some of them also to BAX/BAK. This causes killing of tumour cells via a BAX/BAK-dependent mechanism. ${ }^{162-164}$ 
However, as ABT-737 and ABT-263 bind only a subset of the $\mathrm{BCL}-2$-like pro-survival proteins, overexpression of MCL1 or A1/BFL-1, both of which are not inhibited by these compounds, has the potential to confer resistance to therapy. ${ }^{164}$ Some cancers (such as CLL) with very high expression of BCL-2 (and possibly also cancers expressing high levels of $\mathrm{BCL}-\mathrm{XL}$ and/or BCL-W) respond robustly to the existing $\mathrm{BH} 3-$ mimetics when used as single agents. However, in order to maximise treatment efficacy, in many cancers these $\mathrm{BH}$ mimetics are probably best employed in combination with drugs known to activate $\mathrm{BH}$ 3-only proteins, such as BIM or PUMA, that can potently neutralise MCL-1 and/or A1.

Indeed BH3-mimetics have been found to potently synergise in vitro with various chemotherapeutic drugs in the killing of $\mathrm{CLL}^{165}$ and many other cancer cells, including mouse xenograft models of human breast cancer. ${ }^{152,153,157,166,167}$ Such combinatorial therapeutic strategies would effectively neutralise all pro-survival BCL-2 family proteins and thereby efficiently activate apoptosis in malignant cells.

BH3-mimetics also affect non-transformed cells; for example, ABT-737 and ABT-263 cause thrombocytopaenia because platelets rely on BCL-XL for their survival. ${ }^{168,169}$ This problem can be circumvented in the context of BCL-2dependent tumours by using ABT-199/venetoclax, a BH3mimetic that only inhibits BCL-2 and is showing great promise for the treatment of CLL. ${ }^{170}$ Moreover, to prevent unacceptable collateral damage to normal tissues, $\mathrm{BH} 3$-mimetics may best be used in combination therapies with drugs that only affect cancer cells, such as inhibitors of oncogenic kinases (e.g., Gleevec to inhibit BCR-ABL in CML, Vemurafenib to inhibit mutant BRAF in melanoma), rather than using them with cytotoxic drugs that cause DNA damage in both malignant as well as non-transformed cells. ${ }^{160}$

\section{Concluding Remarks}

Changes in expression and activity of members of the BCL-2 family (and their upstream regulators) can exert profound effects of cell survival and this is of particular relevance to the development of cancer and its clinical treatment. Mechanisms delineated using mouse models mimicking human malignancies have greatly advanced our understanding of how apoptosis suppresses tumour formation. Importantly, these findings have been mirrored by insights from clinical studies and this knowledge can now be harnessed to develop improved treatment strategies for patients. So far, the most exciting outcome from these advances has been the development of the BH3-mimetic drugs that directly activate apoptosis in cancer cells by binding and inhibiting select prosurvival BCL-2 family members. The first of such compounds, ABT-263/navitoclax and ABT-199/venetoclax, are currently generating much excitement as they progress through clinical trials and will hopefully prove efficacious for treatment of a wide variety of both haematological and solid cancers.

\section{Conflict of Interest}

ARD Delbridge and A Strasser are employed by The Walter and Eliza Hall Institute. The Walter and Eliza Hall Institute receives milestone payments from Genentech and AbbVie for the development of $\mathrm{BH} 3$-mimetics for cancer therapy.
Acknowledgements. We thank Dr. JM Adams, Dr. S Cory, Dr. P Bouillet, Dr. M Herold, Dr. D Gray, Dr. LA O'Reilly, Dr. S Grabow, Dr. G Kelly, Dr. A Janic, Dr. S Alvarez-Diaz, Dr. F Ke, Dr. B Aubrey, Dr. LValente, Dr. C Vandenberg, Dr. A Kueh, J Low, L Rohrbeck, R Schenk, M Brennan, R Salvamoser and B Yang for insightful discussions. This work was supported by grants and fellowships from the Cancer Council of Victoria (ARDD, Sydney Parker Smith Postdoctoral Research Fellowship), the National Health and Medical Research Council (Program Grant no.1016701; NHMRC SPRF Fellowship 1020363 to AS) and the Leukemia and Lymphoma Society (SCOR Grant no. 7001-13), Australian Postgraduate Award (to ARDD) and Cancer Therapeutics CRC Top-up Scholarship (to ARDD). This work was made possible by operational infrastructure grants through the Australian Government IRISS and the Victorian State Government OIS.

1. Strasser A, O'Connor L, Dixit VM. Apoptosis signaling. Ann Rev Biochem 2000; 69: 217-245.

2. Delbridge AR, Valente LJ, Strasser A. The role of the apoptotic machinery in tumor suppression. Cold Spring Harb Perspect Biol 2012; 4: 11.

3. Hanahan D, Weinberg RA. Hallmarks of cancer: the next generation. Cell 2011; 144: 646-674.

4. Hotchkiss RS, Strasser A, McDunn JE, Swanson PE. Cell death. New Engl J Med 2009; 361: 1570-1583.

5. Lamkanfi M, Dixit VM. Mechanisms and functions of inflammasomes. Cell 2014; 157: 1013-1022.

6. Linkermann A, Green DR. Necroptosis. N Engl J Med 2014; 370: 455-465.

7. Kerr JFR, Wyllie AH, Currie AR. Apoptosis: a basic biological phenomenon with wideranging implications in tissue kinetics. Brit J Cancer 1972; 26: 239-257.

8. Farbman Al. Electron microscope study of palate fusion in mouse embryos. Dev Biol 1968; 18: 93-116.

9. Klion FM, Schaffner F. The ultrastructure of acidophilic "Councilman-like" bodies in the liver. Am J Pathol 1966; 48: 755-767.

10. Kerr JF. An electron-microscope study of liver cell necrosis due to heliotrine. J Pathol 1969; 97: $557-562$.

11. Hengartner MO, Horvitz HR. C. elegans cell survival gene ced-9 encodes a functional homolog of the mammalian proto-oncogene bcl-2. Cell 1994; 76: 665-676.

12. Vaux DL, Weissman IL, Kim SK. Prevention of programmed cell death in Caenorhabditis elegans by human bcl-2. Science 1992; 258: 1955-1957.

13. Lee EF, Clarke OB, Evangelista M, Feng Z, Speed TP, Tchoubrieva EB et al. Discovery and molecular characterization of a Bcl-2-regulated cell death pathway in schistosomes. Proc Natl Acad Sci USA 2011; 108: 6999-7003.

14. Strasser A, Cory S, Adams JM. Deciphering the rules of programmed cell death to improve therapy of cancer and other diseases. EMBO J 2011; 30: 3667-3683.

15. Youle RJ, Strasser A. The BCL-2 protein family: opposing activities that mediate cell death. Nat Rev Mol Cell Biol 2008; 9: 47-59.

16. Lessene G, Czabotar PE, Colman PM. BCL-2 family antagonists for cancer therapy. Nat Rev Drug Discov 2008; 7: 989-1000.

17. Davids MS, Letai A. Targeting the B-cell lymphoma/leukemia 2 family in cancer. J Clin Oncol 2012; 30: 3127-3135.

18. Moldoveanu T, Follis AV, Kriwacki RW, Green DR. Many players in BCL-2 family affairs. Trends Biochem Sci 2014; 39: 101-111.

19. Czabotar PE, Lessene G, Strasser A, Adams JM. Control of apoptosis by the BCL-2 protein family: implications for physiology and therapy. Nat Rev Mol Cell Biol 2014; 15: 49-63.

20. Suzuki M, Youle RJ, Tjandra N. Structure of Bax: coregulation of dimer formation and intracellular localization. Cell 2000; 103: 645-654.

21. Czabotar PE, Westphal D, Dewson G, Ma S, Hockings C, Fairlie WD et al. Bax crystal structures reveal how $\mathrm{BH} 3$ domains activate Bax and nucleate its oligomerization to induce apoptosis. Cell 2013; 152: 519-531.

22. Willis SN, Chen L, Dewson G, Wei A, Naik E, Fletcher Jl et al. Proapoptotic Bak is sequestered by $\mathrm{Mcl}-1$ and $\mathrm{Bcl}-\mathrm{xL}$, but not $\mathrm{Bcl}-2$, until displaced by $\mathrm{BH} 3-$ only proteins. Gene Dev 2005; 19: 1294-1305.

23. Willis SN, Fletcher Jl, Kaufmann T, van Delft MF, Chen L, Czabotar PE et al. Apoptosis initiated when BH3 ligands engage multiple Bcl-2 homologs, not Bax or Bak. Science 2007; 315: 856-859.

24. Ke F, Voss A, Kerr JB, O'Reilly LA, Tai L, Echeverry N et al. BCL-2 family member BOK is widely expressed but its loss has only minimal impact in mice. Cell Death Differ 2012; 19: 915-925.

25. Ke F, Bouillet P, Kaufmann T, Strasser A, Kerr J, Voss AK. Consequences of the combined loss of BOK and BAK or BOK and BAX. Cell Death Dis 2013; 4: e650.

26. Huang DCS, Strasser A. BH3-only proteins - essential initiators of apoptotic cell death. Cell 2000; 103: 839-842.

27. Happo L, Strasser A, Cory S. BH3-only proteins in apoptosis at a glance. J Cell Sci 2012; 125: 1081-1087.

28. Hinds MG, Smits C, Fredericks-Short R, Risk JM, Bailey M, Huang DC et al. Bim, Bad and Bmf: intrinsically unstructured $\mathrm{BH}$-only proteins that undergo a localized conformational change upon binding to prosurvival Bcl-2 targets. Cell Death Differ 2007;14: 128-136. 
29. Chou JJ, Li H, Salvesen GS, Yuan J, Wagner G. Solution structure of BID, an intracellular amplifier of apoptotic signaling. Cell 1999; 96: 615-624.

30. McDonnell JM, Fushman D, Milliman CL, Korsmeyer SJ, Cowburn D. Solution structure of the proapoptotic molecule BID: a structural basis for apoptotic agonists and antagonists. Cell 1999; 96: 625-634.

31. Chen L, Willis SN, Wei A, Smith BJ, Fletcher Jl, Hinds MG et al. Differential targeting of pro-survival Bcl-2 proteins by their BH3-only ligands allows complementary apoptotic function. Mol Cell 2005; 17: 393-403.

32. Kuwana T, Bouchier-Hayes L, Chipuk JE, Bonzon C, Sullivan BA, Green DR et al. $\mathrm{BH} 3$ domains of $\mathrm{BH}$-only proteins differentially regulate Bax-mediated mitochondrial membrane permeabilization both directly and indirectly. Mol Cell 2005; 17: 525-535.

33. Opferman JT, Letai A, Beard C, Sorcinelli MD, Ong CC, Korsmeyer SJ. Development and maintenance of B and T lymphocytes requires antiapoptotic MCL-1. Nature 2003; 426: 671-676.

34. Leshchiner ES, Braun CR, Bird GH, Walensky LD. Direct activation of full-length proapoptotic BAK. Proc Natl Acad Sci USA 2013; 110: E986-E995.

35. Gavathiotis E, Reyna DE, Bellairs JA, Leshchiner ES, Walensky LD. Direct and selective small-molecule activation of proapoptotic BAX. Nat Chem Biol 2012; 8: 639-645.

36. Gavathiotis E, Reyna DE, Davis ML, Bird GH, Walensky LD. BH3-triggered structural reorganization drives the activation of proapoptotic BAX. Mol Cell 2010; 40: 481-492.

37. Gavathiotis E, Suzuki M, Davis ML, Pitter K, Bird GH, Katz SG et al. BAX activation is initiated at a novel interaction site. Nature 2008; 455: 1076-1081.

38. Merino D, Giam M, Hughes PD, Siggs OM, Heger K, O'Reilly LA et al. The role of BH3-only protein Bim extends beyond inhibiting Bcl-2-like prosurvival proteins. J Cell Biol 2009; 186: 355-362.

39. Wei MC, Lindsten T, Mootha VK, Weiler S, Gross A, Ashiya M et al. tBID, a membranetargeted death ligand, oligomerizes BAK to release cytochrome c. Genes Dev 2000; 14: 2060-2071.

40. Chipuk JE, Green DR. How do BCL-2 proteins induce mitochondrial outer membrane permeabilization? Trends Cell Biol 2008; 18: 157-164.

41. Llambi F, Moldoveanu T, Tait SW, Bouchier-Hayes L, Temirov J, McCormick LL et al. A unified model of mammalian BCL-2 protein family interactions at the mitochondria. Mol Cell 2011; 44: 517-531.

42. Puthalakath $\mathrm{H}$, Strasser A. Keeping killers on a tight leash: transcriptional and posttranslational control of the pro-apoptotic activity of $\mathrm{BH} 3-$ only proteins. Cell Death Differ 2002; 9: 505-512.

43. Nakano K, Vousden KH. PUMA, a novel proapoptotic gene, is induced by p53. Mol Cell 2001; 7: 683-694.

44. Yu J, Zhang L, Hwang PM, Kinzler KW, Vogelstein B. PUMA induces the rapid apoptosis of colorectal cancer cells. Mol Cell 2001; 7: 673-682.

45. Oda E, Ohki R, Murasawa H, Nemoto J, Shibue T, Yamashita T et al. Noxa, a BH3-only member of the bcl-2 family and candidate mediator of p53-induced apoptosis. Science 2000; 288: 1053-1058.

46. Hershko $\mathrm{T}$, Ginsberg D. Up-regulation of BCl-2 homology $3(\mathrm{BH} 3)$-only proteins by E2F1 mediates apoptosis. J Biol Chem 2004; 279: 8627-8634.

47. Dijkers PF, Medema RH, Lammers JJ, Koenderman L, Coffer PJ. Expression of the pro-apoptotic Bcl-2 family member Bim is regulated by the forkhead transcription factor FKHR-L1. Curr Biol 2000; 10: 1201-1204.

48. Ekoff M, Kaufmann T, Engstrom M, Motoyama N, Villunger A, Jonsson $\mathrm{Jl}$ et al. The BH3-only protein Puma plays an essential role in cytokine deprivation-induced apoptosis of mast cells. Blood 2007; 110: 3209-3217.

49. You H, Pellegrini M, Tsuchihara K, Yamamoto K, Hacker G, Erlacher M et al. FOXO3a-dependent regulation of Puma in response to cytokine/growth factor withdrawal. J Exp Med 2006; 203: 1657-1663.

50. Herold MJ, Rohrbeck L, Lang MJ, Grumont R, Gerondakis S, Tai L et al. Foxo-mediated Bim transcription is dispensable for the apoptosis of hematopoietic cells that is mediated by this BH3-only protein. EMBO Rep 2013; 14: 992-998.

51. Puthalakath H, O'Reilly LA, Gunn P, Lee L, Kelly PN, Huntington ND et al. ER stress triggers apoptosis by activating BH3-only protein Bim. Cell 2007; 129: 1337-1349.

52. Balmanno K, Cook SJ. Tumour cell survival signalling by the ERK1/2 pathway. Cell Death Differ 2009; 16: 368-377.

53. del Peso L, González-Garcia M, Page C, Herrera R, Nuñez G. Interleukin-3-induced phosphorylation of BAD through the protein kinase Akt. Science 1997; 278: 687-689.

54. Ranger AM, Zha J, Harada H, Datta SR, Danial NN, Gilmore AP et al. Bad-deficient mice develop diffuse large B cell lymphoma. Proc Natl Acad Sci USA 2003; 100: 9324-9329.

55. Kelly PN, White MJ, Goschnick MW, Fairfax KA, Tarlinton DM, Kinkel SA et al. Individual and overlapping roles of BH3-only proteins Bim and Bad in apoptosis of lymphocytes and platelets and in suppression of thymic lymphoma development. Cell Death Differ 2010; 17: 1655-1664.

56. Ley R, Hadfield K, Howes E, Cook SJ. Identification of a DEF-type docking domain for extracellular signal-regulated kinases $1 / 2$ that directs phosphorylation and turnover of the BH3-only protein BimEL. J Biol Chem 2005; 280: 17657-17663.

57. Clybouw C, McHichi B, Mouhamad S, Auffredou MT, Bourgeade MF, Sharma S et al. EBV infection of human $B$ lymphocytes leads to down-regulation of Bim expression: relationship to resistance to apoptosis. J Immunol 2005; 175: 2968-2973.
58. Luciano F, Jacquel A, Colosetti P, Herrant M, Cagnol S, Pages G et al. Phosphorylation of Bim-EL by Erk $1 / 2$ on serine 69 promotes its degradation via the proteasome pathway and regulates its proapoptotic function. Oncogene 2003; 22: 6785-6793.

59. Ley R, Balmanno K, Hadfield K, Weston C, Cook SJ. Activation of the ERK1/2 signaling pathway promotes phosphorylation and proteasome-dependent degradation of the $\mathrm{BH} 3$ only protein, Bim. J Biol Chem 2003; 278: 18811-18816.

60. Akiyama T, Bouillet P, Miyazaki T, Kadono Y, Chikuda H, Chung UI et al. Regulation of osteoclast apoptosis by ubiquitylation of proapoptotic BH3-only Bcl-2 family member Bim. EMBO J 2003; 22: 6653-6664.

61. Clybouw C, Merino D, Nebl T, Masson F, Robati M, O'Reilly L et al. Alternative splicing of Bim and Erk-mediated Bim(EL) phosphorylation are dispensable for hematopoietic homeostasis in vivo. Cell Death Differ 2012; 19: 1060-1068.

62. Puthalakath H, Huang DCS, O'Reilly LA, King SM, Strasser A. The pro-apoptotic activity of the Bcl-2 family member Bim is regulated by interaction with the dynein motor complex. Mol Cell 1999; 3: 287-296.

63. Puthalakath H, Villunger A, O'Reilly LA, Beaumont JG, Coultas L, Cheney RE et al. Bmf: a pro-apoptotic $\mathrm{BH} 3$-only protein regulated by interaction with the myosin $\mathrm{V}$ actin motor complex, activated by anoikis. Science 2001; 293: 1829-1832.

64. Jurado S, Gleeson K, O'Donnell K, Izon DJ, Walkley CR, Strasser A et al. The Zinc-finger protein ASCIZ regulates B cell development via DYNLL1 and Bim. J Exp Med 2012; 209: 1629-1639.

65. Ventura A, Young AG, Winslow MM, Lintault L, Meissner A, Erkeland SJ et al. Targeted deletion reveals essential and overlapping functions of the mIR-17 $~ 92$ family of miRNA clusters. Cell 2008; 132: 875-886.

66. Xiao C, Srinivasan L, Calado DP, Patterson HC, Zhang B, Wang J et al. Lymphoproliferative disease and autoimmunity in mice with increased miR-17-92 expression in lymphocytes. Nat Immunol 2008; 9: 404-414.

67. Ambs S, Prueitt RL, Yi M, Hudson RS, Howe TM, Petrocca F et al. Genomic profiling of microRNA and messenger RNA reveals deregulated microRNA expression in prostate cancer. Cancer Res 2008; 68: 6162-6170.

68. Fontana L, Fiori ME, Albini S, Cifaldi L, Giovinazzi S, Forloni M et al. Antagomir-17-5p abolishes the growth of therapy-resistant neuroblastoma through p21 and BIM. PLOS One 2008; 3: e2236.

69. Kan T, Sato F, Ito T, Matsumura N, David S, Cheng Y et al. The miR-106b-25 polycistron, activated by genomic amplification, functions as an oncogene by suppressing p21 and Bim. Gastroenterology 2009; 136: 1689-1700.

70. Veronese A, Lupini L, Consiglio J, Visone R, Ferracin M, Fornari F et al. Oncogenic role of miR-483-3p at the IGF2/483 locus. Cancer Res 2010; 70: 3140-3149.

71. Zhang CZ, Zhang JX, Zhang AL, Shi ZD, Han L, Jia ZF et al. MiR-221 and miR-222 target PUMA to induce cell survival in glioblastoma. Mol Cancer 2010; 9: 229.

72. Xiong $Y$, Fang JH, Yun JP, Yang J, Zhang $Y$, Jia WH et al. Effects of microRNA-29 on apoptosis, tumorigenicity, and prognosis of hepatocellular carcinoma. Hepatology 2010; 51: 836-845.

73. Mott JL, Kobayashi S, Bronk SF, Gores GJ. mir-29 regulates Mcl-1 protein expression and apoptosis. Oncogene 2007; 26: 6133-6140.

74. Xu J, Liao X, Wong C. Downregulations of B-cell lymphoma 2 and myeloid cell leukemia sequence 1 by microRNA 153 induce apoptosis in a glioblastoma cell line DBTRG-05MG. Int J Cancer 2010; 126: 1029-1035.

75. Cimmino A, Calin GA, Fabbri M, lorio MV, Ferracin M, Shimizu M et al. miR-15 and miR-16 induce apoptosis by targeting BCL2. Proc Natl Acad Sci USA 2005; 102: 13944-13949.

76. Liu L, Chen L, Xu Y, Li R, Du X. microRNA-195 promotes apoptosis and suppresses tumorigenicity of human colorectal cancer cells. Biochem Biophys Res Commun 2010; 400: 236-240.

77. Bommer GT, Gerin I, Feng Y, Kaczorowski AJ, Kuick R, Love RE et al. p53-mediated activation of miRNA34 candidate tumor-suppressor genes. Curr Biol 2007; 17: 1298-1307.

78. Nakano H, Miyazawa T, Kinoshita K, Yamada Y, Yoshida T. Functional screening identifies a microRNA, miR-491 that induces apoptosis by targeting $\mathrm{Bcl}-\mathrm{X}(\mathrm{L})$ in colorectal cancer cells. Int J Cancer 2010; 127: 1072-1080.

79. Strasser A. The role of BH3-only proteins in the immune system. Nat Rev Immuno/ 2005; 5 : 189-200.

80. Soucek L, Evan Gl. The ups and downs of Myc biology. Curr Opin Genet Dev 2010; 20: 91-95.

81. Adams JM, Harris AW, Pinkert CA, Corcoran LM, Alexander WS, Cory S et al. The c-myc oncogene driven by immunoglobulin enhancers induces lymphoid malignancy in transgenic mice. Nature 1985; 318: 533-538.

82. Langdon WY, Harris AW, Cory S, Adams JM. The c-myc oncogene perturbs B lymphocyte development in $\mathrm{E} \mu$-myc transgenic mice. Cell 1986; 47: 11-18.

83. Harris AW, Pinkert CA, Crawford M, Langdon WY, Brinster RL, Adams JM. The E $\mu$-myc transgenic mouse: a model for high-incidence spontaneous lymphoma and leukemia of early B cells. J Exp Med 1988; 167: 353-371.

84. Evan Gl, Wyllie AH, Gilbert CS, Littlewood TD, Land H, Brooks M et al. Induction of apoptosis in fibroblasts by c-myc protein. Cell 1992; 69: 119-128.

85. Strasser A, Elefanty AG, Harris AW, Cory S. Progenitor tumours from Em-bcl-2-myc transgenic mice have lymphomyeloid differentiation potential and reveal developmental differences in cell survival. EMBO J 1996; 15: 3823-3834. 
86. Strasser A, Harris AW, Bath ML, Cory S. Novel primitive lymphoid tumours induced in transgenic mice by cooperation between myc and bcl-2. Nature 1990; 348 331-333.

87. Swanson PJ, Kuslak SL, Fang W, Tze L, Gaffney P, Selby S et al. Fatal acute lymphoblastic leukemia in mice transgenic for B cell-restricted bcl-xL and c-myc. J Immunol 2004; 172 6684-6691.

88. Campbell KJ, Bath ML, Turner ML, Vandenberg CJ, Bouillet P, Metcalf D et al. Elevated Mcl-1 perturbs lymphopoiesis, promotes transformation of hematopoietic stem/progenito cells, and enhances drug resistance. Blood 2010; 116: 3197-3207.

89. Egle A, Harris AW, Bouillet P, Cory S. Bim is a suppressor of Myc-induced mouse B cell leukemia. Proc Natl Acad Sci USA 2004; 101: 6164-6169.

90. Delbridge AR, Grabow S, Bouillet P, Adams JM, Strasser A. Functional antagonism between pro-apoptotic BIM and anti-apoptotic BCL-XL in MYC-induced lymphomagenesis. Oncogene 2014; 34: 1872-1876.

91. Michalak EM, Jansen ES, Happo L, Cragg MS, Tai L, Smyth GK et al. Puma and to a lesser extent Noxa are suppressors of Myc-induced lymphomagenesis. Cell Death Differ 2009; 16 : 684-696.

92. Eischen CM, Roussel MF, Korsmeyer SJ, Cleveland JL. Bax loss impairs Myc-induced apoptosis and circumvents the selection of p53 mutations during Myc-mediated lymphomagenesis. Mol Cell Biol 2001; 21: 7653-7662.

93. Kelly PN, Grabow S, Delbridge ARD, Strasser A, Adams JM. Endogenous Bcl-xL is essential for Myc-driven lymphomagenesis in mice. Blood 2011; 118: 6380-6386.

94. Kelly PN, Grabow S, Delbridge AR, Adams JM, Strasser A. Prophylactic treatment with the BH3 mimetic ABT-737 impedes Myc-driven lymphomagenesis in mice. Cell Death Diffe 2013; 20: 57-63.

95. Kelly PN, Puthalakath $\mathrm{H}$, Adams JM, Strasser A. Endogenous bcl-2 is not required for the development of $\mathrm{E} \mu$-myc-induced B-cell lymphoma. Blood 2007; 109: 4907-4913.

96. Letai A, Sorcinelli MD, Beard C, Korsmeyer SJ. Antiapoptotic BCL-2 is required for maintenance of a model leukemia. Cancer Cell 2004; 6: 241-249.

97. Kelly GL, Grabow S, Glaser SP, Fitzsimmons L, Aubrey BJ, Okamoto T et al. Targeting of MCL-1 kills MYC-driven mouse and human lymphomas even when they bear mutations in p53. Genes Dev 2014; 28: 58-70.

98. Hollstein M, Sidransky D, Vogelstein B, Harris CC. p53 mutations in human cancers Science 1991; 253: 49-53.

99. Nigro JM, Baker SJ, Preisinger AC, Jessup JM, Hostetter R, Cleary K et al. Mutations in the p53 gene occur in diverse human tumour types. Nature 1989; 342: 705-708.

100. Malkin D, Li FP, Strong LC, Fraumeni JFJ, Nelson CE, Kim DH et al. Germ line p53 mutations in a familial syndrome of breast cancer, sarcomas, and other neoplasms. Science 1990; 250: 1233-1238.

101. Srivastava S, Zou ZQ, Pirollo K, Plattner W, Chang EH. Germ-line transmission of mutated p53 gene in a cancer-prone family with Li-Fraumeni syndrome. Nature 1990; 348 : 747-749.

102. Donehower LA, Harvey M, Slagle BL, McArthur MJ, Montgomery CAJ, Butel JS et al. Mice deficient for p53 are developmentally normal but are susceptible to spontaneous tumours. Nature 1992; 356: 215-221.

103. Jacks T, Remington L, Williams BO, Schmitt EM, Halachmi S, Bronson RT et al. Tumor spectrum analysis in p53-mutant mice. Curr Biol 1994; 4: 1-7.

104. Michalak EM, Villunger A, Adams JM, Strasser A. In several cell types the tumour suppressor p53 induces apoptosis largely via Puma but Noxa can contribute. Cell Death Differ 2008; 15: 1019-1029.

105. Li T, Kon N, Jiang L, Tan M, Ludwig T, Zhao Y et al. Tumor suppression in the absence of p53-mediated cell-cycle arrest, apoptosis, and senescence. Cell 2012; 149: 1269-1283.

106. Brady CA, Jiang D, Mello SS, Johnson TM, Jarvis LA, Kozak MM et al. Distinct p53 transcriptional programs dictate acute DNA-damage responses and tumor suppression. Cell 2011; 145: 571-583.

107. Valente LJ, Gray DH, Michalak EM, Pinon-Hofbauer J, Egle A, Scott CL et al. p53 efficiently suppresses tumor development in the complete absence of its cell-cycle inhibitory and proapoptotic effectors p21, Puma, and Noxa. Cell reports 2013; 3: 1339-1345.

108. Grabow S, Delbridge AR, Valente LJ, Strasser A. MCL-1 but not BCL-XL is critical for the development and sustained expansion of thymic lymphoma in p53-deficient mice. Blood 2014; 124: 3939-3946.

109. Kaplan HS. The role of radiation on experimental leukemogenesis. Natl Cancer Inst Monog 1964; 14: 207-220.

110. Labi V, Erlacher M, Kiessling S, Manzl C, Frenzel A, O'Reilly L et al. Loss of the BH3-only protein Bmf impairs $B$ cell homeostasis and accelerates gamma irradiation-induced thymic lymphoma development. J Exp Med 2008; 205: 641-655

111. Michalak EM, Vandenberg CJ, Delbridge ARD, Wu L, Scott CL, Adams JM et al. Apoptosispromoted tumorigenesis: gamma-irradiation-induced thymic lymphomagenesis requires Puma-driven leukocyte death. Genes Dev 2010; 24: 1608-1613.

112. Labi V, Erlacher M, Krumschnabel G, Manzl C, Tzankov A, Pinon J et al. Apoptosis of leukocytes triggered by acute DNA damage promotes lymphoma formation. Genes Dev 2010; 24: 1602-1607.

113. Glaser S, Lee EF, Trounson E, Bouillet P, Wei A, Fairlie WD et al. Anti-apoptotic Mcl-1 is essential for the development and sustained growth of acute myeloid leukemia. Genes Dev 2012; 26: 120-125.
114. Xiang Z, Luo H, Payton JE, Cain J, Ley TJ, Opferman JT et al. Mcl1 haploinsufficiency protects mice from Myc-induced acute myeloid leukemia. J Clin Invest 2010; 120: 2109-2118.

115. Tsujimoto Y, Yunis J, Onorato-Showe L, Erikson J, Nowell PC, Croce CM. Molecular cloning of the chromosomal breakpoint of B-cell lymphomas and leukemias with the $\mathrm{t}(11 ; 14)$ chromosome translocation. Science 1984; 224: 1403-1406.

116. Vaux DL, Cory S, Adams JM. Bcl-2 gene promotes haemopoietic cell survival and cooperates with c-myc to immortalize pre-B cells. Nature 1988; 335: 440-442.

117. Castle VP, Heidelberger KP, Bromberg J, Ou X, Dole M, Nuñez G. Expression of the apoptosis-suppressing protein $b c l-2$ in neuroblastoma is associated with unfavorable histology and N-myc amplification. Am J Pathol 1993; 143: 1543-1550.

118. Pepper C, Hoy T, Bentley P. Elevated Bcl-2/Bax are a consistent feature of apoptosis resistance in B-cell chronic lymphocytic leukaemia and are correlated with in vivo chemoresistance. Leuk Lymphoma 1998; 28: 355-361.

119. Pepper C, Hoy T, Bentley DP. Bcl-2/Bax ratios in chronic lymphocytic leukaemia and their correlation with in vitro apoptosis and clinical resistance. Br J Cancer 1997; 76: 935-938.

120. Pepper C, Bentley P, Hoy T. Regulation of clinical chemoresistance by bcl-2 and bax oncoproteins in B-cell chronic lymphocytic leukaemia. Br J Haematol 1996; 95: 513-517.

121. Beroukhim R, Mermel C, Porter D, Wei G, Raychaudhuri S, Donovan J et al. The landscape of somatic copy-number alteration across human cancers. Nature 2010; 463: 899-905.

122. Tonon G, Wong KK, Maulik G, Brennan C, Feng B, Zhang Y et al. High-resolution genomic profiles of human lung cancer. Proc Natl Acad Sci USA 2005; 102: 9625-9630.

123. Smith LT, Mayerson J, Nowak NJ, Suster D, Mohammed N, Long $\mathrm{S}$ et al. 20q11.1 amplification in giant-cell tumor of bone: array CGH, FISH, and association with outcome. Genes Chromosomes Cancer 2006; 45: 957-966.

124. Park IC, Lee SH, Whang DY, Hong WS, Choi SS, Shin HS et al. Expression of a novel Bcl-2 related gene, Bfl-1, in various human cancers and cancer cell lines. Anticancer Res 1997; 17: 4619-4622.

125. Morales AA, Olsson A, Celsing F, Osterborg A, Jondal M, Osorio LM. High expression of bfl-1 contributes to the apoptosis resistant phenotype in B-cell chronic lymphocytic leukemia. Int J Cancer 2005; 113: 730-737.

126. Olsson A, Norberg M, Okvist A, Derkow K, Choudhury A, Tobin G et al. Upregulation of bfl-1 is a potential mechanism of chemoresistance in B-cell chronic lymphocytic leukaemia. Br J Cancer 2007; 97: 769-777.

127. Rampino N, Yamamoto H, Ionov Y, Li Y, Sawai H, Reed JC et al. Somatic frameshift mutations in the bax gene in colon cancers of the microsatellite mutator phenotype. Science 1997; 275: 967-969.

128. Tagawa H, Karnan S, Suzuki R, Matsuo K, Zhang X, Ota A et al. Genome-wide array-based CGH for mantle cell lymphoma: identification of homozygous deletions of the proapoptotic gene BIM. Oncogene 2005; 24: 1348-1358.

129. Richter-Larrea JA, Robles EF, Fresquet V, Beltran E, Rullan AJ, Agirre X et al. Reversion of epigenetically mediated BIM silencing overcomes chemoresistance in Burkitt lymphoma. Blood 2010; 116: 2531-2542.

130. Garrison SP, Jeffers JR, Yang C, Nilsson JA, Hall MA, Rehg JE et al. Selection against PUMA gene expression in Myc-driven B-cell lymphomagenesis. Mol Cell Biol 2008; 28: 5391-5402.

131. Wick W, Petersen I, Schmutzler RK, Wolfarth B, Lenartz D, Bierhoff E et al. Evidence for a novel tumor suppressor gene on chromosome 15 associated with progression to a metastatic stage in breast cancer. Oncogene 1996; 12: 973-978.

132. Strasser A, Harris AW, Cory S. Bcl-2 transgene inhibits T cell death and perturbs thymic self-censorship. Cell 1991; 67: 889-899.

133. Strasser A, Harris AW, Jacks T, Cory S. DNA damage can induce apoptosis in proliferating lymphoid cells via p53-independent mechanisms inhibitable by Bcl-2. Cell 1994; 79: 329-339.

134. Huang DCS, Cory S, Strasser A. Bcl-2, Bcl-XL and adenovirus protein E1B19kD are functionally equivalent in their ability to inhibit cell death. Oncogene 1997; 14: 405-414.

135. Lindemann RK, Newbold A, Whitecross KF, Cluse LA, Frew AJ, Ellis L et al. Analysis of the apoptotic and therapeutic activities of histone deacetylase inhibitors by using a mouse model of B cell lymphoma. Proc Natl Acad Sci USA 2007; 104: 8071-8076.

136. Frew AJ, Lindemann RK, Martin BP, Clarke CJ, Sharkey J, Anthony DA et al. Combination therapy of established cancer using a histone deacetylase inhibitor and a TRAIL receptor agonist. Proc Natl Acad Sci USA 2008; 105: 11317-11322.

137. Newbold A, Lindemann RK, Cluse LA, Whitecross KF, Dear AE, Johnstone RW. Characterisation of the novel apoptotic and therapeutic activities of the histone deacetylase inhibitor romidepsin. Mol Cancer Ther 2008; 7: 1066-1079.

138. Lindsten T, Ross AJ, King A, Zong W, Rathmell JC, Shiels HA et al. The combined functions of proapoptotic Bcl-2 family members Bak and Bax are essential for normal development of multiple tissues. Mol Cell 2000; 6: 1389-1399.

139. Rathmell JC, Lindsten T, Zong W-X, Cinalli RM, Thompson CB. Deficiency in Bak and Bax perturbs thymic selection and lymphoid homeostasis. Nat Immunol 2002; 3: 932-939.

140. Mason KD, Lin A, Robb L, Josefsson EC, Henley KJ, Gray DH et al. Proapoptotic Bak and Bax guard against fatal systemic and organ-specific autoimmune disease. Proc Natl Acad Sci USA 2013; 110: 2599-2604. 
141. Villunger A, Michalak EM, Coultas L, Mullauer F, Bock G, Ausserlechner MJ et al. p53- and drug-induced apoptotic responses mediated by $\mathrm{BH} 3$-only proteins puma and noxa. Science 2003; 302: 1036-1038.

142. Jeffers JR, Parganas E, Lee $\mathrm{Y}$, Yang $\mathrm{C}$, Wang J, Brennan $\mathrm{J}$ et al. Puma is an essential mediator of p53-dependent and -independent apoptotic pathways. Cancer Cell 2003; 4 : 321-328.

143. Erlacher M, Michalak EM, Kelly PN, Labi V, Niederegger H, Coultas L et al. BH3-only proteins Puma and Bim are rate-limiting for \{gamma\} -radiation and glucocorticoid-induced apoptosis of lymphoid cells in vivo. Blood 2005; 106: 4131-4138.

144. Naik E, Michalak EM, Villunger A, Adams JM, Strasser A. UV-radiation triggers apoptosis of fibroblasts and skin keratinocytes mainly via the BH3-only protein Noxa. J Cell Biol 2007; 176: 415-424.

145. Happo L, Cragg MS, Phipson B, Haga JM, Jansen ES, Herold MJ et al. Maximal killing of lymphoma cells by DNA-damage inducing therapy requires not only the p53 targets Puma and Noxa but also Bim. Blood 2010; 116: 5256-5267.

146. Erlacher M, Laabi V, Manzl C, Bock G, Tzankov A, Haecker G et al. Puma cooperates with $\mathrm{Bim}$, the rate-limiting $\mathrm{BH} 3$-only protein in cell death during lymphocyte development, in apoptosis induction. J Exp Med 2006; 203: 2939-2951.

147. Ploner C, Rainer J, Niederegger H, Eduardoff M, Villunger A, Geley S et al. The BCL2 rheostat in glucocorticoid-induced apoptosis of acute lymphoblastic leukemia. Leukemia 2008; 22: 370-377.

148. Molitoris JK, McColl KS, Distelhorst CW. Glucocorticoid-mediated repression of the oncogenic microRNA cluster miR-17 92 contributes to the induction of Bim and initiation of apoptosis. Mol Endocrinol 2011; 25: 409-420.

149. Abrams MT, Robertson NM, Yoon K, Wickstrom E. Inhibition of glucocorticoid-induced apoptosis by targeting the major splice variants of BIM mRNA with small interfering RNA and short hairpin RNA. J Biol Chem 2004; 279: 55809-55817.

150. Bouillet $P$, Metcalf D, Huang DCS, Tarlinton DM, Kay TWH, Köntgen F et al. Proapoptotic $\mathrm{Bcl}-2$ relative Bim required for certain apoptotic responses, leukocyte homeostasis, and to preclude autoimmunity. Science 1999; 286: 1735-1738.

151. Sunters A, Fernandez de Mattos S, Stahl M, Brosens JJ, Zoumpoulidou G, Saunders $\mathrm{CA}$ et al. FoxO3a transcriptional regulation of $\mathrm{Bim}$ controls apoptosis in paclitaxel-treated breast cancer cell lines. J Biol Chem 2003; 278 : 49795-49805.

152. Cragg MS, Jansen ES, Cook M, Strasser A, Scott CL. Treatment of B-RAF mutant human tumor cells with a MEK inhibitor requires Bim and is enhanced by a $\mathrm{BH} 3$ mimetic. $J$ Clin Invest 2008; 118: 3651-3659.

153. Cragg MS, Kuroda J, Puthalakath H, Huang DCS, Strasser A. Gefitinib-induced killing of NSCLC cell lines expressing mutant EGFR requires Bim and can be enhanced by $\mathrm{BH} 3$ mimetics. PLOS Med 2007; 4: 1681-1689.

154. Costa DB, Halmos B, Kumar A, Schumer ST, Huberman MS, Boggon TJ et al. BIM mediates EGFR tyrosine kinase inhibitor-induced apoptosis in lung cancers with oncogenic EGFR mutations. PLoS Med 2007; 4: e315.
155. Gong Y, Somwar R, Politi K, Balak M, Chmielecki J, Jiang X et al. Induction of BIM is essential for apoptosis triggered by EGFR kinase inhibitors in mutant EGFR-dependent lung adenocarcinomas. PLoS Med 2007; 4: e294.

156. Kuribara R, Honda H, Matsui $H$, Shinjyo $T$, Inukai $T$, Sugita $K$ et al. Roles of Bim in apoptosis of normal and Bcr-Abl-expressing hematopoietic progenitor. Mol Cell Biol 2004 24: 6172-6183.

157. Kuroda J, Puthalakath H, Cragg MS, Kelly PN, Bouillet P, Huang DC et al. $\mathrm{Bim}$ and Bad mediate imatinib-induced killing of Bcr/Abl+ leukemic cells, and resistance due to their loss is overcome by a BH3 mimetic. Proc Natl Acad Sci USA 2006; 103: 14907-14912.

158. Naik E, O'Reilly LA, Asselin-Labat ML, Merino D, Lin A, Cook M et al. Destruction of tumor vasculature and abated tumor growth upon VEGF blockade is driven by proapoptotic protein Bim in endothelial cells. J Exp Med 2011; 208: 1351-1358.

159. Ng KP, Hillmer AM, Chuah CT, Juan WC, Ko TK, Teo AS et al. A common BIM deletion polymorphism mediates intrinsic resistance and inferior responses to tyrosine kinase inhibitors in cancer. Nat Med 2012; 18: 521-528.

160. Cragg MS, Harris $C$, Strasser A, Scott CL. Unleashing the power of inhibitors of oncogenic kinases through BH3 mimetics. Nat Rev Cancer 2009; 9: 321-326.

161. Oltersdorf T, Elmore SW, Shoemaker AR, Armstrong RC, Augeri DJ, Belli BA et al. An inhibitor of Bcl-2 family proteins induces regression of solid tumours. Nature 2005; 435 $677-681$.

162. Tse C, Shoemaker AR, Adickes J, Anderson MG, Chen J, Jin S et al. ABT-263: a potent and orally bioavailable Bcl-2 family inhibitor. Cancer Res 2008; 68: 3421-3428.

163. van Delft MF, Wei AH, Mason KD, Vandenberg CJ, Chen L, Czabotar PE et al. The BH3 mimetic ABT-737 targets selective Bcl-2 proteins and efficiently induces apoptosis via Bak Bax if Mcl-1 is neutralized. Cancer Cell 2006; 10: 389-399.

164. Merino D, Khaw SL, Glaser SP, Anderson DJ, Belmont LD, Wong C et al. Bcl-2, Bcl-x(L), and $\mathrm{Bcl}-\mathrm{w}$ are not equivalent targets of ABT-737 and navitoclax (ABT-263) in lymphoid and leukemic cells. Blood 2012; 119: 5807-5816.

165. Mason KD, Khaw SL, Rayeroux KC, Chew E, Lee EF, Fairlie DW et al. The BH3 mimetic compound, ABT-737, synergizes with a range of cytotoxic chemotherapy agents in chronic lymphocytic leukemia. Leukemia 2009; 23: 2034-2041.

166. Oakes SR, Vaillant F, Lim E, Lee L, Breslin K, Feleppa F et al. Breast Cancer Special Feature: sensitization of $\mathrm{BCL}$-2-expressing breast tumors to chemotherapy by the $\mathrm{BH} 3$ mimetic ABT-737. Proc Natl Acad Sci USA 2012; 109: 2766-2771.

167. Mason KD, Vandenberg CJ, Scott CL, Wei AH, Cory S, Huang DC et al. In vivo efficacy of the Bcl-2 antagonist ABT-737 against aggressive Myc-driven lymphomas. Proc Natl Acad Sci USA 2008; 105: 17961-17966.

168. Mason KD, Carpinelli MR, Fletcher JI, Collinge JE, Hilton AA, Ellis S et al. Programmed anuclear cell death delimits platelet life span. Cell 2007; 128: 1173-1186.

169. Zhang H, Nimmer PM, Tahir SK, Chen J, Fryer RM, Hahn KR et al. Bcl-2 family proteins are essential for platelet survival. Cell Death Differ 2007; 14: 943-951.

170. Souers AJ, Leverson JD, Boghaert ER, Ackler SL, Catron ND, Chen J et al. ABT-199, a potent and selective BCL-2 inhibitor, achieves antitumor activity while sparing platelets. Nat Med 2013; 19: 202-208. 